\title{
Populism, Sovereigntism, and the Unlikely Re- Emergence of the Territorial Nation-State
}

\author{
Aristotle Kallis ${ }^{1}$
}

Received: 5 March 2018/Accepted: 11 May 2018/Published online: 30 May 2018

(C) The Author(s) 2018

\begin{abstract}
In the last three decades, the rise of a populist challenge to the liberal political mainstream exposed how shallow the supposed victory of global liberalism was, even in its heartlands in Europe and North America. Exclusive nationalism and nativism, identity politics, critiques of globalisation and internationalism, and calls for democratic re-empowerment of the demos have converged politically on a new locus of inflated territorial, indeed 'border' sovereignty, aligning the call of 'taking back control' on behalf of a radically re-defined community ('we') with a defensive re-territorialisation of power along existing fault lines of nation-statism. In this paper, I argue that the very same call has become the new common political denominator for all populist platforms and parties across Europe. I argue that populists across the conventional left-right divide have deployed a rigidly territorialised concept of popular sovereignty in order to bestow intellectual coherence and communicative power to the otherwise disparate strands of their anti-utopian critiques of globalisation. In spite of significant ideological differences between socalled right- and left-wing populism, in the short-term the two populist projects have sought to stage their performances of sovereigntism on, behind or inside the borders of the existing nation-states.
\end{abstract}

Keywords Populism $\cdot$ Sovereignty $\cdot$ State $\cdot$ Power $\cdot$ Border

After seemingly emerging strengthened from the First World War, liberalism suffered the political equivalent of near-death in the 1930s, attacked from illiberal and anti-liberal forces from left and right in large parts of the world. Against many

Aristotle Kallis

a.kallis@keele.ac.uk

1 School of Humanities, Keele University, CBB1.040, Chancellor's Building, Keele ST5 5BG, UK 
odds, the period after 1945 gave liberalism a new lease of life. In spite of the division of the world into two ideological opposed camps, the liberal project flourished in 'the west', gathered momentum post-1968, became a seemingly unassailable 'regime of truth' by the end of the century, and sought to become a universalisable paradigm of political order on a global scale. The dramatic events of 1989-1991 surrounding the collapse of the Soviet bloc and the end of the Cold War nurtured the illusion of a near-victory for this very liberal project on a near-global scale (Fukuyama 2006; Judis 2016).

Since the turn of the new millennium, however, the illusion has started to turn into a nightmare. The rise of a multifaceted populist challenge to the liberal political mainstream exposed how shallow the supposed victory of liberalism was, even in its heartlands in Europe and North America (Moffitt 2016; Kaltwasser 2015). Exclusive nationalism and nativism, identity politics, critiques of globalisation and internationalism, increasingly bolder re-assertions of localised sovereignty - all increased their noise and mounted challenges that have tested the liberal reflexes and found them crumbling. Amidst this challenge, the project of liberal universalism (in its various iterations as economic globalisation, universality of human rights, liberal internationalism, political federalism, cosmopolitanism, multiculturalism etc.-Charvet and Kaczynska-Nay 2008) came under sustained attack from a resurgent version of the paradigm of populist nation-statism. Sovereignty is at the very heart of this challenge; it is its primary justification, diagnosis, and roadmap of radical change for the future. 'Taking back control' is the standard rallying cry on behalf of a radically re-defined community ('we'). It became the-very effective, as it turned out-rallying cry for the campaign to take the United Kingdom out of the European Union during the 2016 referendum. But I will argue that the very same call, in different discursive articulations, has become the critical common political denominator for all populist platforms and parties across Europe. In its own way, the vision has functioned as a powerful anti-utopia, a call to action in order to avert a perceived unfolding catastrophe, first, by projecting as a warning an extreme version of the present and, second, by offering an alternative path to a better future (Levitas 1990, 165-167; Kumar 1987).

By all standards, 'taking back control' is an evocative discursive construction (Pabst 2018). It projects agency and foreshadows the moral urgency of wholesale redress. It communicates a rupture with the present and posits a desirable future destination. It is anti-utopian in its critique of 'the right to imperfection' (Berdyaev 2009, 187-188) and its associated rejection of a putative liberal universal 'totality'. But it is also pointing to the possibility of $e u$ topia (a better alternative place) that is not just wishful thinking but possible and actionable. By 'taking back control' one both actively prevents the unfolding of catastrophe and helps realise the normative claim of an allegedly better future. Thus, the critical tension between what 'is' and what 'ought to be' is mediated by the dawning of a new radical potentialityinstead of what 'should be', what 'could be' (Arditi 2007, 126-127). 'Taking back control' is the anti-utopian means to an end and the eutopian end itself; a kind of 'enacted utopia' that celebrates every small victory as the triumphant performance of the alternative future in the present (Sargisson 2012, 35-36); a realised countersite, however small or partial, that underlines its difference from the other-still 
dominant-liberal, internationalist, and globalising counter-spaces that it rejects and subverts.

The call to 'take back control', whether articulated in these words or inferred from other related discursive formations, is simple and resonant. Nevertheless, its perceived simplicity belies a density of anti-utopian critique and counter-utopian proposition. Leaving aside for the moment the vision of 'taking control', the formulation consists of four critical components-who must take control; from whol where this control should be wrested; how this control will be taken back; and where this control will be brought as a prized trophy. Theories on contemporary populism have answered convincingly the first three of these questions. According to the classic definition by Cas Mudde, populism is an ideology that considers society to be divided into two antagonistic groups, the homogeneous 'people' and the corrupt 'elite'. In this bottom-up alternative vision to the current reality of establishment politics increasingly distant from the concerns of 'real' people, populists argue that politics should be an expression of the general will of the people (Mudde 2004). It is this homogeneous 'people' that is juxtaposed to the forces of internationalism, globalisation, and cultural diversity, which are articulated as direct threats to its existential security. This schema brings together a range of otherwise disparate targets-neo-liberal global elites and 'shadowy' transnational interests; the European Union in both its political and economic integrative functions; US economic, political, and military hegemony; immigration flows; and multiculturalism (Zaslove 2008). Control, therefore, needs to be wrested from these sources of power through a number of strategies, including economic nationalism and an embrace of protectionism, political chauvinism, isolationism, reassertion of strict border controls, reversal of previous international commitments, and an expansive range of discriminatory measures targeting those excluded from the narrow definition of 'the people'.

It is the fourth component that interests me in this paper-the where to. I argue that populists have deployed an extreme concept of popular sovereignty-what Spiro, speaking in relation to the US context, referred to as 'new sovereigntism' (cf. Ladi 2007) - in order to bestow intellectual coherence and communicative power to the disparate strands of their anti-utopian programmes. This political alliance between populism and sovereigntism has been articulated on the basis of respatialising power. The diagnosis is that such power has been slipping away for a long time, becoming more distant from the community and abused by external forces; but this process, it is argued, has now reached a tipping point, putting at direct risk the welfare of the community itself. Against the backdrop of a shrinking, diffuse, decentred, and unfamiliar world, where the infrastructure of globalisation is very much in place, the conventional political, cultural, social, and territorial entity of the nation-state becomes a legitimate and above all familiar and reassuring model to re-imagine and articulate this project of reclaiming sovereignty. Thus, the populist attack on the post-war globalising liberalism gives the traditional nationstate an unlikely new lease of life, in stark contrast to earlier confident prognoses that the era of the nation-state is drawing to a close. What is even more striking, I argue, is that nation-statism has become the locus of a convergence between populist platforms from both the right and the left. In arguing so, I do not seek to 
play down the significant intellectual differences between the two platforms (or indeed to apply the term 'populism' uncritically to both). I do, however, seek to draw parallels in terms of their respective use of sovereignty as a discourse of popular mobilisation and to point out how otherwise very different claims for taking back control have resulted in a joint project to legitimise the re-concentration of power within the historic territorial contours and by the institutions of the nationstate.

\section{Back to the Future: From Nation-Statism to Post-sovereigntism... to Nation-Statism}

Back in the heady days of the early 1990s, the Scottish professor of law Neil MacCormick made a passionate case against a sovereign-based legal and political international order. Viewed from a contemporary vintage point, the tone of his language underlines eloquently how the debate has shifted in the intervening quarter of a century:

There is a widespread, but perhaps misguided, belief that there are a lot of sovereign states in the world, that this is a good thing ... A different view would be that sovereignty and sovereign states, and the inexorable linkage of law with sovereignty and the state, have been but the passing phenomena of a few centuries, that their passing is by no means regrettable, and that current developments in Europe exhibit the possibility of going beyond all that. On this view, our passing beyond the sovereign state is to be considered a good thing, an entirely welcome development in the history of legal and political ideas. (MacCormick 1993, 1).

The kind of de facto passing of the so-called Westphalian system of sovereign nation-states that MacCormick was celebrating in 1993 has been repeatedly proclaimed in the post-1945 period. Both international and transnational institutions and norms, it has been argued, have consistently eroded the sovereignty of traditional states-the majority of which have been constituted and behaved as nation-states. This is a process that is not unique to the post-World War II period. In fact, what modern political thinkers define as the 'Westphalian system' corresponds only partly and imperfectly with the granular reality of politics and international relations in the past four centuries. As Krasner $(2001,22)$ notes, the view that the erosion of traditional state sovereignty since 1945 is an exceptional trend is in itself 'myopic'. It assumes that there was a golden era of state sovereignty that puts the twentieth century at odds with the Westphalian model; and yet various levels and degrees of compromise and conflict, resulting in contestation, cession or loss of sovereignty, have marked the entire history of the sovereign nation-state. Nevertheless, it is possible to argue that the contradictions and flimsy assumptions of the Westphalian model have been unravelling faster and more extensively. Challenges have come from both outside the state (trans- and international) and inside it (sub-national) (Guéhenno 1995). As a result, state sovereignty has been receding by choice and necessity alike. On the one hand, nation-states have ceded 
voluntarily significant aspects — in varying degrees — of their sovereignty to a higher level of governance. On the other hand, the growing corpus of international obligations and the proliferation of transnational flows in the globalising world have de facto diluted or infringed on the norms of Westphalian sovereignty (Cuchillo 2006).

But does all this amount to a genuine post-Westphalian/sovereigntist turn? In the last two decades of the twentieth century, a number of academics, politicians, and journalists wore their confident belief in the demise of the old Westphalian world on their sleeves. The growth of inter- and transnational trade; the dramatic proliferation of international organisations and of their ability to influence decisions; the exponential expansion of technological interconnectedness; all pointed, it seemed to them, to the dawn of a new epoch of globalisation that was disrupting beyond redress the traditional authority of the nation-state (Rosenberg 2005, 3-5). Writing on the cusp of the new millennium, Elemer Hankiss discussed the globalisationnation state dialectics and identified five main scenarios for the future. In four out of these scenarios, the power of the nation-state would suffer decline-a decline that ranged from outright implosion to transformation into an unrecognisable new political and social settlement, a 'post-modern' nation-state. Only one scenario envisaged the strengthening of the power of the nation-state-and this would be only be in the direction of growing authoritarianism (Hankiss 1999, 135-137). Still, in all scenarios, the fate of the nation-state was directly linked to the dynamics and direction of globalisation, the latter being the major determining factor of the future international constellation. Tellingly, the 350th anniversary of the signing of the Treaty of Westphalia came and passed with little fanfare in 1998 (Osiander 2001).

The prospect of a post-Westphalian future looks much less plausible from the vantage point of 2018. Since the turn of the millennium, a new era of sovereigntism has been predicated on the urgent need to reverse the trend of political and economic globalisation as inherently undemocratic and dangerous to the interests of the people (Goodhart and Taninchev 2011). The confident predictions of the 1990s regarding the wholesale universalisation of the liberal settlement, let alone about its unabashed final victory at the end of the historical time (Fukuyama 2006), appear nothing less than hubristic today. It is supranational organisations and initiatives like the EU or the International Criminal Court (Scheipers 2013, 82-102), rather than nation-states, that now fight to shore up their political legitimacy against calls for scaling back or abandoning altogether the vision of global governance.

Still, on the eve of the hundredth anniversary of the end of World War I, one would be forgiven for confessing to a disquieting sense of déjà vue. Boyce (2009, 1-22) has used historical analogy in order to stress that the world may have been in a not-too-dissimilar place before-a place where globalisation failed at the time of its seeming triumph, where liberalism imploded while apparently triumphant and approaching something akin the 'end of history'. After emerging from the First World War seemingly triumphant and on the road to a kind of an unprecedented kind of political hegemony, liberalism suffered the political equivalent of near-death in the 1930s, attacked from illiberal and anti-liberal forces from left and right in large parts of the world. Meanwhile what one may refer to as globalisation, already in motion since the early nineteenth century, gathered unprecedented pace in the 
1920s only to plunge into a dual crisis of economic activity and political legitimacy in the 1930s (Boyce 2009, 3-5). From the vantage point of 1939 and without the benefit of historical hindsight, liberalism seemed on its last leg, without much of a future beyond a few islands of exception (Fawcett 2015, 198-284). By contrast, nation-statism appeared on the cusp of re-defining the entire global political order. A utopian project at its core envisaging an ideal fusion between a strong, expanded state encompassing the entirety of a homogeneous national community, initially it took on a more pragmatic and moderate form as part of the post-1918 peace deliberations, in the form of national self-determination tempered by liberal guarantees for constitutional minority rights. However, a far more extreme, indeed chillingly utopian form of literal and aggressive nation-statism came to the fore in the 1920s and vied for supremacy in the 1930s (Mann 2004a, b, 1-92) - and did so largely by taking advantage of liberal inaction in the face of a crisis that turned the presumed certainties of the post-WW1 world upside down (Boyce 2009, 19-22). Liberal elites held an exaggerated view about the resilience of the global(ising) order that they presided over post-1918, under-estimated the extent of the antiliberal challenge from different sides, and over-estimated (in some cases massively) the degree of popular support that existed even in core constituencies for their brand of brave political and economic new world. Fascism found in nation-statism a utopian project that ticked the primary boxes of strong and authoritarian government, organic national unity, and aggressive, uncompromising pruning of the national community from foes, threats, and alien elements (Mann 1997, 476-478).

Against many odds, 1945 marked the collapse of fascism as a mainstream political project. The period after 1945 gave the gasping liberalism of the interwar years a surprising new lease of life, a second or indeed unlikely third chance after the setbacks of the two world wars. In spite of the division of the world into two ideologically opposed camps, the liberal project flourished in 'the west' and sought to become a universalisable paradigm of political change on a global scale. Economic globalisation and economic trade, it was argued, would foster ever-closer international ties across the world, thereby minimising the risk of future conflict. Meanwhile, the political manifesto of post-war liberalism, steeped in memories of the two world wars and the brutal extermination of millions of Jews and other minorities, rejected nation-statism in favour of more deliberate diffuse models of political power, more inclusive notions of community membership, and a far stronger role given to inter- and transnational institutions in an attempt to counterpoise the power of the old Westphalian state. In many ways, this is what the Entente planners of Versailles world order had expected to happen-diffusing the power of grand empires into significantly smaller and imperfect nation-states, and then underwriting the risks through a series of inter- and transnational checks and balances. That the post-WW1 order failed so devastatingly to operate in this manner and that the liberal order came so close to being obliterated by the models of concentrated state power that it had attempted to neutralise served a powerful lesson to post-1945 planners. As early as 1931, the British historian of civilisations Arnold Toynbee had declared himself in favour of 'a deliberate and sustained and concentrated effort to impose limitations upon the sovereignty and independence of 
the fifty or sixty local sovereign independent States'. His justification was strikingly predictive of both the calamities that were still to follow and the post-World War II post-sovereigntist counter-attack:

The local national state, invested with the attributes of sovereignty - is an abomination of desolation standing in the place where it ought not. It has stood in that place now - demanding and receiving human sacrifices from its poor deluded votaries - for four or five centuries. Our political task in our generation is to cast the abomination out, to cleanse the temple and to restore the worship of the divinity to whom the temple rightfully belongs. In plain terms, we have to re-transfer the prestige and the prerogatives of sovereignty from the fifty or sixty fragments of contemporary society to the whole of contemporary society - from the local national states by which sovereignty has been usurped, with disastrous consequences, for half a millennium, to some institution embodying our society as a whole. In the world as it is today, this institution can hardly be a universal Church. It is more likely to be something like a League of Nations (Toynbee 1931).

Still, the technology of the old 'local' nation-state that Toynbee exorcised in 1931 and Carr (1945, 47-48) declared as historically inadequate in 1945 could not and would not simply wither away. Even at the very peak of scholarly optimism as to potential of globalisation to erode the grip of the nation-state over sovereign power and territory, Saskia Sassen painted a mixed picture as an alternative to the simplistic zero-sum confrontation between internationalism and nationalism. She did argue that 'sovereignty has been decentred and territory partly denationalized'; but she also added an important caveat:

Sovereignty remains a feature of the system, but it is now located in a multiplicity of institutional arenas: the new emergent transnational private legal regimes, new supranational organizations (such as the WTO and the institutions of the European Union), and the various international human rights codes. All these institutions constrain the autonomy of national states; states operating under the rule of law are caught in a web of obligations they cannot disregard easily. ... What $I$ see is the beginning of an unbundling of sovereignty as we have known it for many centuries. ... But it seems to me that rather than sovereignty eroding as a consequence of globalization and supranational organizations, it is being transformed (Sassen 1996, 29-30).

It could also be argued that the political and institutional parabola of what is now known as the European Union has ventured further and more swiftly than any other post-war institution from conventional understandings of national sovereignty. The combination of political expansion, socio-economic integration, institutional elaboration, and removal of boundaries in key areas from trade to currency exchanges to citizen migration challenged many of the assumptions about the ineliminable core of nation-state sovereignty and the existence of a bounded political community at its very heart (Laffan et al. 2013, 15-17). Giving up such powers originally rooted in the very exercise of sovereignty was - and remains - a voluntary act decided by the nationstates as government and people. The entire discourse of 'post-sovereignty' 
(MacCormick 2002) has drawn most of its legitimacy by precisely anticipating its fiercest critique - the resulting loss of sovereignty and the possibility that this outcome was an irreversible one. It was at this point that the argument of pooling sovereignty struck deliberately at the heart of the 'zero-sum' logic of the sovereign pool. Simply put, it was not argued that pooled sovereignty is a variable-sum game with a positive balance sheet, whereby one's perceived loss is no competitor's equivalent gain or indeed may produce multiple gains in power and prosperity for all (Oduntan 2015, 29; Sweeney 2005). MacCormick recast the link between sovereignty and the modern state with a help of a memorable analogy:

Where at some time past there were, or may have been, sovereign states, there has now been a pooling or a fusion within the communitarian normative order of some of the states' powers of legislation, adjudication and implementation of law in relation to a wide but restricted range of subjects.... We must not envisage sovereignty as the object of some kind of zero sum game, such that the moment $\mathbf{X}$ loses it $\mathbf{Y}$ necessarily has it. Let us think of it rather more as of virginity, which can in at least some circumstances be lost to the general satisfaction without anybody else gaining it (MacCormick 1993: 16; emphasis added).

The critique of conventional understandings of sovereignty, first, as fixed on a bounded (national) territory and, second, as a finite, 'zero-sum' entity challenged the assumed conceptual dependence of sovereignty and the territory of the modern nation-state (Agnew 2005, 439). This is not to question in the slightest that the success and resilience of sovereignty as a principle of the modern state system owes a crucial lot to its territorial underpinnings (Barnett 1996; Murphy 1996); but it does reflect the Zeitgeist of the 1990s - a confident conviction that the growing gap between juridical (de iure) and new forms of effective (de facto) sovereignty had rendered traditional understandings of territoriality and power unfit for a globalised world. From economic flows to legal and judicial pluralism, from mass migration movements to security threats, from disruptive forms of knowledge economy to plural citizenships, the notion of a territorially bounded exercise of sovereignty was found to be inadequate. In the face of all these and other challenges to its territorial constitution, the contemporary state is not necessarily less powerful-but it is significantly less sovereign in effect.

\section{Populism and Sovereigntism}

At the heyday of the liberal confidence in globalisation's irreversible forward March, Dani Rodrik struck a discordant note when he spoke of the danger that this same globalisation was advancing much faster than our ability to govern it or indeed our capacity to comprehend it; and this situation was likely to generate a backlash against it (Rodrik 1997, 45). ${ }^{1}$ Hans-Georg Betz spoke of the 'new politics of

\footnotetext{
${ }^{1}$ See also Saval (2017) 'Globalisation: the rise and fall of an idea that swept the world', The Guardian, 14 July. http://www.theguardian.com/world/2017/jul/14/globalisation-the-rise-and-fall-of-an-idea-thatswept-the-world.
} 
resentment' when he accounted for the early signs of a radical right-wing electoral resurgence in the early 1990s amidst an atmosphere of growing insecurity and fluidity (Betz 1993, 424). The intensity and magnitude of the challenge may not have been clearly evident then but the key ingredients of a backlash were very much in place long before the 2008 global financial crisis-a perception that too much national control had been ceded to distant or diffuse centres of power (Auer 2017); that political decisions made by governments no longer represented the interests of the people; and that, because of the above, governments appeared increasingly incapable of fostering security and identity when this was most needed. As Wallace (1999, 521) noted with regard to the EU in 1999, while most of the 'substance of European state sovereignty has now fallen away, the symbols, the sense of national solidarity, the focus for political representation and accountability, nevertheless remain'. The tentative prediction offered by Rodrik (1997)—that 'the government would come under severe pressure from workers to restrict international economic integration'-could easily be translated in the field of governance too. With the benefit of just enough hindsight, he argued in 2011 that it had become practically impossible to pursue at the same time democracy, a strict definition of sovereignty, and unfettered globalisation.

Within only a few years, it would seem, the world moved incongruously from a globalisation Zeitgeist to a nationalist-populist one (Mudde 2004). The orthodoxies underpinning the confident belief in the seemingly unstoppable forward drive of globalisation and internationalism started giving way to doubts, then to panic reactions, and finally to antagonistic 'zero-sum' alternative perspectives that entered the political and social mainstream with striking ease. In his historical survey of the concept of sovereignty, Hinsley $(1986,2)$ found that articulations of sovereignty tend to be more pronounced and widespread when 'conditions have been producing rapid changes in the scope of government or in the nature of society or in both'. I would argue that this observation is more relevant to perceptions of effective sovereignty rather than to the actual legal constitution thereof. As early as 1960, Elmer E. Schattschneider analysed how ordinary people find themselves increasingly cut off from influencing democratic decision-making-by all accounts one of the most foundations of modern democratic politics - and have thus been reduced to a 'semi-sovereign' status (Schattschneider 1960; van Biezen 2014, 531). This trend of sovereignty slipping away from democratic polity, as Mair $(2013,2)$ has argued, is now reaching the point of transforming the people into a 'non-sovereign' actor.

It is precisely from the launchpad of democratic self-determination that contemporary populists have attacked the rapid growth of inter- and transnational channels that has been the hallmark of globalisation (Goodhart and Taninchev 2011). Populism has emerged as an increasingly powerful and attractive political bulwark and redress to liberal democracy and globalisation (Dobrescu 2017, 68-69). As a discourse, it is centred on an understanding of politics as an antagonistic relationship between 'the people' and 'the (power-wielding but inherently perceived as illegitimate and unaccountable) elite' (Stavrakakis and Katsambekis 2014; Laclau 2005). The jury may still be out on the question of whether this understanding of populism qualifies it as an ideology in its own right, even a 'thin-centred' one (Stanley 2008; Mudde and Kaltwasser 2013, 2017). For the 
purpose of my analysis, I approach populism as both a 'political strategy of exercising power based on direct, unmediated ... support from ... largely unorganised followers' (Weyland 2017, 50; emphasis added); and a discursive filter akin to a schema that recasts conventional, often antinomic political problems and goals in a more way that resonates to contemporary audiences.

It is on this basis that I seek to understand the contemporary populist challenge as closely coupled with a new form of sovereigntism that traverses conventional political divides and extends beyond the critique of any particular sphere or institution. Strictly speaking, the two components of this composite phenomenon have their separate conceptual and political histories (De Spiegeleire et al. 2017); but taken together they represent a significant amplification of the sovereigntist discourse that is both quantitative and qualitative. While in quantitative terms it represents a dramatic intensification of the attack on the legitimacy of political, economic, and cultural globalisation as an elite-driven project, in qualitative terms it amounts to a recasting of this project as a composite threat to the security and prosperity of 'the people' and posits a credible and actionable alternative vision of governance. The associated hardening of the 'zero-sum' perspective on sovereignty that has been the node of contemporary populist discourses across the world underlines the necessity of not just arresting the process of transfer of power away from the territorial state but of reversing the flow altogether.

But is this particular understanding of sovereigntism robust enough in conceptual terms to overcome conventional divides between right and left, 'exclusive' (that is, predominantly identitarian) and 'inclusive' (that is pluralist and socio-economically driven) populism (Mudde and Kaltwasser 2012; de la Torre 2014)? Writing about the rise of SYRIZA in crisis-hit Greece, Stavrakakis and Katsambekis (2014, 137-138) have turned the question on its head, arguing that, while so-called contemporary 'inclusive' alternatives to liberal democracy observed in Latin America and southern Europe may be fruitfully analysed as 'populist' (de la Torre 2016), the term may not be appropriate for the 'exclusionary', hyper-nationalist and even racist discourses emanating from the radical right. This and other similar critiques of the semantic conflation of right- and left-wing operationalisations of 'the people' into a single 'populist' label have evinced an objection to treating the common component-the invocation of 'the people'-in isolation from its perceived 'other' - elites versus under-privileged, such as immigrants, refugees etc. (di Tella 1997, 189). For this reason, I wish to proffer sovereigntism and the reterritorialisation of state power that it effectively promotes as a potential way out of this methodological cul-de-sac. But in order to articulate what is genuinely new about the contemporary coupling of populism and sovereigntism, I wish to focus less on the actual legal dimensions of sovereign power than on the locus of the performance of sovereignty (Moffitt 2016; Blü \& Butzlaff 2018). Staging emotive spectacles of reclaimed sovereign power is an essential facet of the populist strategy that seeks to juxtapose such performances of a re-empowered demos to the alternative of a profound systemic crisis that threatened the very security and welfare of the people (Taggart 2000). In this respect, any project that seeks the reterritorialisation of power as an antidote to a perceived crisis point derived from decades of outflows to ever-distant, unaccountable or unrepresentative global 
centres must draw a new line of defence; a line that both continues to underline the danger 'outside' and celebrates the reconstitution of popular sovereignty 'inside'.

\section{The Border as the Locus of the Populist Performance of 'Taking Back Control'}

We have thus reached the border, the most tangible and symbolic marker of sovereignty in the history of the modern state. The border is a central component of the operation of sovereignty in international law since it is through it that the territory of one state (and thus its legal jurisdiction) is separated from another. This border, the theatre of the most brutal episodes in recent and distant history, the locus of traditional conceptions of sovereignty from Jean Bodin and Thomas Hobbes to Carl Schmitt (Mostov 2008, 19-24), the border that according to globalisation theorists only two decades ago was becoming porous, waning or disappearing altogether as a temporary phase in the history of sovereignty, that same border is being re-constituted as a place of physical and figurative action (Rudolph 2005). In historical terms, borders have served a number of practical purposes on behalf of the nation-state. I will single out four: giving a sense of exclusive, secure space to the community of citizens inside; creating a delineated territorial and political sphere that roots and protects the right to popular self-determination; marking the geographic contours of cultural and historic identities that were at the heart of the bounded community that they enclosed in opposition to surrounding 'others'; and controlling movements in and out of the bounded state (Longo 2017). In all these functions, the state border is a marker that is both physical and symbolic, inclusionary and exclusionary.

The paradox of the border in the contemporary globalised world is that its symbolic significance as the locus of performing sovereignty has increased exponentially at the same time that the state's ability to supervise it as the marker of its full de lure jurisdiction has declined markedly (Ganster and Lorey 2005, xi). The sovereigntists of the populist radical right have come to view it as a bulwark of a nativist, homogeneous community against incursions from people, ideas, commodities, and any other flow from the perceived 'outside' that could threaten the identity and welfare of the bounded community. Their conception of sovereignty is inextricably linked with the physical, legal, and symbolic performance of sovereignty at the border, the point where full bio-political control can be enacted over the bodies of those arriving; and where the full spectacle of legal and political self-determination can be performed vis-a-vis the outside world (Vaughan-Williams 2015). It is of course far from coincidence that during the campaign for the referendum on the British membership of the EU, the Leave campaign used the imagery of the border as the most eloquent marker of the difference between in and out, between a crisis-ridden present and an alternative future of re-territorialised popular self-determination: on the one hand, there was the prospect of reinstating full sovereign control over national borders, the promise to substantially cut migration, and the prospect of clawing back powers that would belong exclusively to the UK Parliament; on the other hand, there was 'Brussels' - a distant city, capital 
of another state, seat of a powerful, elitist international organisation, synonym of a federalist bureaucracy that was the exact opposite of what the sovereigntist nationstatism stood for.

The 'border sovereignty' obsession of the contemporary populist radical right with immigration has of course its roots in the recasting of a 'post-fascist' right that has unfolded since the 1960s. Ethnopluralism became the ideological fodder for reconstituting national state borders as absolute markers of bounded homogeneous nativist communities against the threat of ever-'softer' borders caused by globalisation, political integration, and the widening of the scope of international human rights law (Mudde 2017, 18-19). Ethnopluralism stated a belief in the difference (but crucially not biological or cultural inferiority) and the incompatibility between different groups. In so doing, it also recast the idea of exclusive, territorially bounded communities for a formally post-racial world while continuing to emphasise the critical significance of the state border as the defender of unique characteristics of the community residing in it (Rydgren 2005, 427).

Precisely because the populist radical right has made such an investment in an extreme zero-sum sovereigntist formula, it is not just sovereignty itself but also its panegyric redemption from the grip of the international/globalised agents that needs to be performed. This performance can take a number of forms, ranging from reinstating hard borders to revoking visa stipulations to enhanced policing and militarisation of the border itself to the threat of deportation to the literalisation of the state border as the marker of a bounded community by building a wall (Brown 2010, 25). At a time when walls and fences proliferate across the globe as last-ditch defences against unpredictable migration flows, as they enact extreme security regimes on the literal and symbolic cusp between 'the people' and the rest, they also perform chimeric tales of nation-state sovereignty as compensation for the increasing inability (or indeed failure) of the Westphalian state to deal effectively with the globalising, trans- and international trends. They turn borders into theatres of performing resistance to the-branded as illegitimate and undemocratic_-diktats of global governance.

The ongoing conflict between the EU and particular member-state governments about the fate of refugees inside the Schengen Area of the union is indicative of both the real and the symbolic performance of sovereignty at the (internal) border. In the midst of the 2015 refugee crisis, the Hungarian government decided to erect a long 'border barrier' along the country's frontier with Serbia and Croatia. While the barrier proved effective in halting the refugee flows into Hungary and diverting them to other parts of the continents, it also staged a theatrical performance of sovereignty as permanent security 'reassurance' to the Hungarian citizens, with a conspicuous consumption of hi-tech policing and surveillance technologies. Meanwhile, in spite of a ruling by the European Court of Justice calling on the Hungarian and Slovak governments to implement the 2015 quota agreement for the relocation of refugees inside the Schengen Area, ${ }^{2}$ the Hungarian PM Viktor Orban has refused to implement it, citing security and identity concerns in relation to the

\footnotetext{
${ }^{2}$ Byrne, Andrew. "EU's Top Court Dismisses Hungary and Slovakia Refugee Complaint." Financial Times, September 6, 2017. https://www.ft.com/content/9116ebbc-92de-11e7-bdfa-eda243196c2c.
} 
refugees. ${ }^{3}$ Thus, notwithstanding threats from the European Commission to sue the two member-state governments, Hungary has successfully defied its international commitments as a member of the EU and has staged an ever-more permissive festival of sovereign authority centred on its border in the buildup to the 8 April 2018 parliamentary elections. ${ }^{4}$ The border barrier both marked the stage of a complex sovereignty competition between the transnational and the national; and indexed a convincing repatriation of sovereign power by the re-territorialised nation-state (Jones et al. 2017, 4). Empowered by the result of a 2016 referendum on the quota obligations that, albeit recording a record-low turnout of just under $40 \%$ and thus declared void, returned a $98 \%$ support for the government's intransigent position, ${ }^{5}$ Orban could effectively claim that he was clawing back sovereign control from distant or invisible elites on behalf of the Hungarian and indeed European people.

The strategy has paid off, as evidenced by the electoral triumph of Fidesz in the 2018 elections (49.27\% of the vote and $2 / 3$ rds majority in the parliament). It is no coincidence that the most effective discourse employed by the Leave campaign during the 2016 EU referendum in the UK focused on the reconstitution of a 'hard' border in relation to immigration and free movement of workers from and to the EU (Goodwin and Milazzo 2017; Curtice 2017; Swales 2016). But it is also true that the 'border sovereignty' platform pursued by the Leave campaign cut across traditional party and ideological lines by also invoking another performance of sovereigntywhat has been generally referred to as 'domestic sovereignty', namely the primary power of the legislative and executive institutions of the state to decide and implement policies within its borders on behalf of its citizens (Herod 2009, 192). The power of popular sovereignty's democratic appeal to 'the people', to the majority of the people as expressed through public debate, voting in elections or in some cases participating in referendums, has been identified as being in a tense relationship with liberalism's emphasis on individual freedoms and constitutional restraints on majority rule (Canovan 2004). Populists have invested their appeal to 'the people' with a powerful claim to seek a corrective to the alleged elitist distortion of or disregard for popular will. Against the backdrop of a crisis of popular representation and legitimacy in contemporary liberal democracy, domestic sovereigntists seek to redeem power on behalf of the previously marginalised majority and the privileged elite minority.

It is when we talk about this 'democratic'/'domestic' dimension of the contemporary populist sovereigntist discourse that boundaries between ideologies and sites of performance of sovereignty become increasingly blurred. A lot has been

\footnotetext{
3 Byrne, Andrew, and Neil Buckley. "Hungary Defies German Call to Accept EU Refugee Ruling." Financial Times, September 13, 2017. https://www.ft.com/content/0396b866-9811-11e7-b83c$9588 \mathrm{e} 51488 \mathrm{a} 0$.

4 "Hungary Builds New High-Tech Border Fence-with Few Migrants in Sight." Reuters, March 2 , 2017. https://www.reuters.com/article/us-europe-migrants-hungary-fence/hungary-builds-new-high-techborder-fence-with-few-migrants-in-sight-idUSKBN1692MH.

5 “What Does Hungary's Migrant Quotas Referendum Mean for Europe?, Human Rights Watch, October 6, 2016. https://www.hrw.org/news/2016/10/06/what-does-hungarys-migrant-quotas-referendum-meaneurope (Accessed 26 February 2018).
} 
said and written about the similarities and differences between the so-called populism of the right and the populism of the left. Mouffe $(2005,67)$ has argued that the political right enjoys no monopoly on populism and that a left-wing populism is possible and is needed urgently in these anti-democratic times. Étienne Balibar has called for a progressive antidote, inspiring and popular enough to weaken the current appeal of exclusive hyper-nationalist and often racist populism of the radical right; in essence, he has sung the praises of a positive populism that sees in the redemption of popular sovereignty the end to the disempowerment of the people by unaccountable regimes (Balibar 2017). It would of course be heuristically unhelpful to simply conflate these rather different counter-propositions that derive from antidiametrical views on the membership of 'the people' and the modalities of power reclaimed on its behalf (Stavrakakis 2014, 512-514). Nevertheless, in heeding Balibar's call to develop an inspiring counter-populism that addresses popular frustrations but channels them into inspiring progressive action and the reclaims the discursive terrain of sovereignty from the far-right, democratic sovereigntists of the left have ended up injecting legitimacy to the old project of re-territorialising the power of the nation-state.

Much that Balibar has evangelised a transnational framework for his positive and emancipatory left-wing populism (Panayotu 2017), the borders of existing nationstates have become an unlikely meeting point between the two competing populist projects. While one side sees the border in terms of defence against the corroding effects of neo-liberal economics, right-wing populists embrace it as the absolute filter of the future membership of the bounded (national) community. For democratic sovereigntist movements like Podemos in Spain, clawing political control back to the level of the nation-state may be more accurately explained as an interim strategy of reversing disempowerment in favour of an emancipatory and inclusive political vision of popular sovereignty (Briziarelli 2017; Vittori 2017; Kioupkiolis 2016). By contrast, the populist sovereigntism of radical right-wing movements like the Front National or the Party for Freedom (PVV) in The Netherlands aspires to the reterritorialisation of sovereign power and the exclusive redefinition of a homogeneous people as the endpoint of a counter-utopian vision (Lahav 2004; Pauwels 2014; Vossen 2016). Still, however different the their performances of sovereignty, the two projects converge on the reinvention of the border-symbolic and physical — of the existing nation-states as the marker of redeemed sovereignty. For the left-wing sovereigntists, the road to the constitution of the desired transnational demos may prove longer, more copious and twisted than originally expected (Moffitt 2017). In the meantime, the re-territorialised sovereignty of the nation-state may prove a cogent, highly attractive, and thus resilient common denominator for sovereigntists across the ideological divide, just like nationalism had always lay at various critical intersections of left- and rightwing projects of Euro-scepticism (Halikiopoulou et al. 2012). 


\section{Conclusions}

Between critiques of globalisation and internationalism, of transnational or supranational or even federal reconfigurations of power and of eroded identities, the territorial nation-state has somehow managed to emerge as the unlikely survivor of the backlash against the post-war liberal global order. Sovereigntism-the belief in the uncontested primacy of national-level politics and the call to recover at this precise level (institutionally as well as territorially) power that has slipped away to more distant and diffuse layers of governance-has emerged as one of the primary ideological-political fault lines of contemporary politics, cutting across conventional left-right divides. This sovereigntist perspective is the primary beneficiary of a multifaceted populist critique of globalisation and the demise of the premise of 'postsovereignty' that was so in vogue only two decades ago. It is benefitting from lying at the point of intersection between rival populist projects of re-defining and allegedly re-empowering the community of 'the people' against distant, detached or unaccountable elites. It is also benefitting from a strong preference for reconceptualising sovereign power along defensive territorial lines, clawing back control behind recognisable frontiers of existing states, on behalf of popular communities residing within the contours of established nation-states. Of course differences between leftand right-wing populist sovereigntist projects are too important not to mentiondifferences in the definition and scope of 'the people', in the character of 'the elites' that are targeted, and in the desired effects of the recovered power. Furthermore, for right-wing populists the re-territorialised sovereignty of the nation-state is the ideologically desired endpoint of their angry politics of backlash, while for their leftwing counterparts it is at best an interim position of pragmatic retrenchment en route to a favoured transnational redefinition of the re-empowered demos. Nevertheless, in the short term the two populist projects have sought to stage their performances of sovereigntist redemption on, behind or inside the borders of the nation-states. In their different ways, the reinstatement of hard borders against refugees and immigrants, the 'taking back control' from international or supranational institutions in the name of empowering the demos, the targeting of diverse 'out-groups' in the context of a zerosum competition for power-all preface a plagiarised spectacle of territorial sovereignty that exudes angst, disorientation, and an exhausted political imaginary typical of an uncertain interregnum (Brown 2017, 51; Pabst 2018).

Open Access This article is distributed under the terms of the Creative Commons Attribution 4.0 International License (http://creativecommons.org/licenses/by/4.0/), which permits unrestricted use, distribution, and reproduction in any medium, provided you give appropriate credit to the original author(s) and the source, provide a link to the Creative Commons license, and indicate if changes were made.

\section{References}

Agnew, J. 2005. Sovereignty Regimes: Territoriality and State Auhtority in Contemporary World Politics. Annals of the Association of American Geographers 95: 437-461.

Arditi, B. 2007. Politics on the Edges of Liberalism: Difference, Populism, Revolution, Agitation. Edinburgh: Edinburgh University Press. 
Auer, Stefan. 2017. Sovereignty Bites Back How Did We Get Here? In Brexit: Sociological Responses, ed. William Outhwaite, 41-53. London: Anthem Press.

Balibar, Etienne. (2017, January 3). Populisme : au miroir américain. Libération. http://www.liberation.fr/ debats/2017/01/03/populisme-au-miroir-americain_1538875. Accessed 3 March2018.

Barnett, Michael. 1996. Sovereignty, Nationalism, and Regional Order in the Arab States System. In State Sovereignty as Social Construct, ed. Cynthia Weber and Thomas J. Biersteker, 148-189. Cambridge: Cambridge University Press.

Berdyaev, N. 2009. The End of Our Time: Together with an Essay on the General Line of Soviet Philosophy. San Rafael, CA: Semantron Press.

Betz, Hans-George. 1993. The New Politics of Resentment: Radical Right-Wing Populist Parties in Western Europe. Comparative Politics 25: 413-427.

Blü, Ingolfur, and Felix Butzlaff. 2018. Rethinking Populism: Peak Democracy, Liquid Identity and the Performance of Sovereignty Towards a Shift of Perspective. European Journal of Social Theory 21: $1-21$.

Boyce, Robert. 2009. The Great Interwar Crisis and the Collapse of Globalization. Basingstoke: Palgrave.

Briziarelli, Marco. 2017. Podemos' Twofold Assault on Hegemony: The Possibilities of the Post-Modern Prince and the Perils or Passive Revolution. In Podemos and the New Political Cycle: Left-Wing Populism and Anti-Establishment Politics, ed. Oscar Garcia Agustin and Marco Briziarelli, 97-122. Palgrave: Basingstoke.

Brown, Wendy. 2017. Walled States, Waning Sovereignty. Cambridge, MA: MIT Press.

Brown, Wendy. 2010. Walled State, Waning Sovereignty. New York, MA: Zone Books.

Canovan, Margaret. 2004. Populism for Political Theorists? Journal of Political Ideologies 9(3): 241-252.

Carr, E.H. 1945. Nationalism and After. London: Macmillan.

Charvet, J., and E. Kaczynska-Nay. 2008. The Liberal Project and Human Rights: The Theory and Practice of a New World Order. Cambridge: Cambridge University Press.

Cuchillo, Montserrat. 2006. The End of Sovereignty? A Transatlantic Perspective. In The End of Sovereignty? A Transatlantic Perspective, ed. David J. Eaton, 97-128. Hamburg: LIT Verlag.

Curtice, John. 2017. Why Leave Won the UK's EU Referendum. JCMS: Journal of Common Market Studies 55(1S): 19-37.

De Spiegeleire, Stephan, Clarissa Skinner, and Tim Sweijs. 2017. The Rise of Populist Sovereignism. The Hague: Centre for Strategic Studies (HCSS).

de la Torre, Carlos. 2014. The Promise and Perils of Populism: Global Perspectives. Lexington: University Press of Kentucky.

de la Torre, Carlos. 2016. Populism and the Politics of the Extraordinary in Latin America. Journal of Political Ideologies 21: 121-139.

di Tella, Torcuato S. 1997. Populism Into the Twenty-First Century. Government and Opposition 32: 187-200.

Dobrescu, P. 2017. The Century of the Emerging World: Development with a Vengeance. Cambridge: Cambridge Scholars Publishing.

Fawcett, E. 2015. Liberalism: The Life of an Idea. Princeton, NJ: Princeton University Press.

Fukuyama, Francis. 2006. The End of History and the Last Man. New York: Free Press.

Ganster, P. and D.E. Lorey (eds.). 2005. Borders and Border Politics in a Globalizing World. Lanham, MD: SR Books.

Goodhart, Michael, and Stacy Bondanella Taninchev. 2011. The New Sovereigntist Challenge for Global Governance: Democracy Without Sovereignty. International Studies Quarterly 55: 1047-1068.

Goodwin, Matthew, and Caitlin Milazzo. 2017. Taking Back Control? Investigating the Role of Immigration in the 2016 Vote for Brexit. The British Journal of Politics and International Relations 19: 450-464.

Guéhenno, Jean-Marie. 1995. The End of the Nation-State. Minneapolis: University of Minnesota Press. Halikiopoulou, Daphne, Kyriaki Nanou, and Sofia Vasilopoulou. 2012. The Paradox of Nationalism: The Common Denominator of Radical Right and Radical Left Euroscepticism. European Journal of Political Research 51: 504-539.

Hankiss, Elemer. 1999. Globalization and the End of the Nation State? World Futures 53: 135-147.

Herod, Andrew. 2009. Geographies of Globalization. A Critical Introduction. Malden, MA: WileyBlackwell.

Hinsley, F.H. 1986. Sovereignty. 2nd ed. Cambridge: Cambridge University Press. 
Jones, Reece, Corey Johnson, Wendy Brown, Gabriel Popescu, Polly Pallister-wilkins, Alison Mountz, Emily Gilbert, Reece Jones, Corey Johnson, and Wendy Brown. 2017. Interventions on the State of Sovereignty at the Border. Political Geography 59: 1-10.

Judis, J.B. 2016. The Populist Explosion: How the Great Recession Transformed American and European Politics. New York: Columbia Global Reports.

Kaltwasser, C.R. 2015. Explaining the Emergence of Populism in Europe and the Americas. In The Promise and Perils of Populism: Global Perspectives, ed. Carlos de la Torre, 189-227. Lexington: University Press of Kentucky.

Kioupkiolis, Alexandros. 2016. Podemos: The Ambiguous Promises of Left-Wing Populism in Contemporary Spain. Journal of Political Ideologies 21: 99-120.

Krasner, Stephen D. 2001. Rethinking the Sovereign State Model. Review of International Studies 27: $17-42$.

Kumar, Krishan. 1987. Utopia and Anti-utopia in Modern Times. Oxford: Blackwell.

Laclau, Ernesto. 2005. On Populist Reason. London: Verso.

Ladi, Z. 2007. The Great Disruption. Cambridge: Polity.

Laffan, B., R.O. Donnell, and M. Smith. 2013. Europe's Experimental Union: Rethinking Integration. London: Routledge.

Lahav, G. 2004. Immigration and Politics in the New Europe: Reinventing Borders. Cambridge: Cambridge University Press.

Levitas, Ruth. 1990. The Concept of Utopia. Utopianism and Communitarianism. Syracuse, NY: Syracuse University Press.

Longo, M. 2017. The Politics of Borders: Sovereignty, Security, and the Citizen after 9/11. Problems of International Politics. Cambridge: Cambridge University Press.

MacCormick, Neil. 2002. Questioning Sovereignty: Law, State, and Nation in the European Commonwealth. Oxford: Oxford University Press.

MacCormick, Neil. 1993. Beyond the Sovereign State. The Modern Law Review 56: 1-18.

Mair, Peter. 2013. Ruling the Void: The Hollowing of Western Democracy. London: Verso.

Mann, Michael. 1997. Has Globalization Ended the Rise and Rise of the Nation-State? Review of International Political Economy 4: 472-496.

Mann, Michael. 2004a. Fascists. Cambridge: Cambridge University Press.

Mann, Michael. 2004b. The Dark Side of Democracy: Explaining Ethnic Cleansing. Cambridge: Cambridge University Press.

Moffitt, Benjamin. 2016. The Global Rise of Populism: Performance, Political Style, and Representation. Stanford, CA: Stanford University Press.

Moffitt, Benjamin. 2017. Transnational Populism? Representative Claims, Media and the Difficulty of Constructing a Transnational 'People'. Javnost 24: 409-425.

Mostov, Julie. 2008. Soft borders: Rethinking Sovereignty and Democracy. Basingstoke: Palgrave.

Mouffe, Chantal. 2005. "The "End of Politics" and the Challenge of Right-Wing Populism. In Populism and the Mirror of Democracy, ed. Francisco Panizza, 50-71. London: Verso.

Mudde, Cas, and Cristóbal Rovira Kaltwasser. 2012. Exclusionary vs. Inclusionary Populism: Comparing Contemporary Europe and Latin America. Government and Opposition 48: 147-174.

Mudde, Cas, and Cristóbal Rovira Kaltwasser. 2013. Populism. In The Oxford Handbook of political Ideologies, ed. Michael Freeden, Lyman Tower Sargent, and Marc Stears, 493-512. Oxford: Oxford University Press.

Mudde, Cas. 2004. The Populist Zeitgeist. Government and Opposition 39: 542-563.

Mudde, Cas. 2017. Populism: An Ideational Approach. In The Oxford Handbook of Populism, ed. C.R. Kaltwasser, P.A. Taggart, P.O. Espejo, and P. Ostiguy, 27-47. Oxford: Oxford University Press.

Murphy, Alexander B. 1996. The Sovereign State System as Political-Territorial Ideal: Historical and Contemporary Considerations. In State Sovereignty as Social Construct, ed. Cynthia Weber and Thomas J. Biersteker, 81-120. Cambridge: Cambridge University Press.

Oduntan, Gbenga. 2015. International Law and Boundary Disputes in Africa. London: Routledge.

Osiander, Andreas. 2001. Sovereignty, International Relations, and the Westphalian Myth. International Organization 55: 251-287.

Pabst, A. 2018. A Post-Liberal World? Constructive Alternatives to Liberal Globalisation Amid the Threat of Neo-Fascism. DOC Research Institute. https://doc-research.org/post-liberal-world/. 5 May 2018.

Panayotu, P. 2017. Towards a Transnational Populism: A Chance for European Democracy (?). POPULISMUS Working Papers 5: 1-23. 
Pauwels, T. 2014. Populism in Western Europe: Comparing Belgium, Germany and The Netherlands. London: Routledge.

Ramiro, L., and R. Gomez. 2017. Radical-Left Populism during the Great Recession: Podemos and Its Competition with the Established Radical Left. Political Studies 65: 108-126.

Rodrik, Dani. 1997. Has Globalization Gone Too Far?. Washington, DC: Institute for International Economics.

Rosenberg, Justin. 2005. Globalization Theory: A Post Mortem. International Politics 42: 2-74.

Rudolph, Christopher. 2005. Sovereignty and Territorial Borders in a Global Age. International Studies Review 7: 1-20.

Rydgren, Jens. 2005. Is Extreme Right-Wing Populism Contagious? Explaining the Emergence of a New Party Family. European Journal of Political Research 44: 413-437.

Sargisson, L. 2012. Fool's Gold? Utopianism in the Twenty-First Century. Basingstoke: Palgrave.

Sassen, Saskia. 1996. Losing Control?: Sovereignty in the Age of Globalization. New York: Columbia University Press.

Schattschneider, Elmer E. 1960. The Semisovereign People: A Realist's View of Democracy in America. New York: Holt, Rinehart and Winston.

Scheipers, S. 2013. Negotiating Sovereignty and Human Rights: International Society and the International Criminal Court. Manchester: Manchester University Press.

Stanley, Ben. 2008. The Thin Ideology of Populism. Journal of Political Ideologies 13: 95-110.

Stavrakakis, Yannis, and Giorgos Katsambekis. 2014. Left-Wing Populism in the European Periphery: The Case of SYRIZA. Journal of Political Ideologies 19: 119-142.

Stavrakakis, Yannis. 2014. The Return of "the People": Populism and Anti-Populism in the Shadow of the European Crisis. Constellations 21: 505-517.

Swales, Kirby. 2016. Understanding the Leave Vote. London: NatCen Social Research. https:// whatukthinks.org/eu/wp-content/uploads/2016/12/NatCen_Brexplanations-report-FINAL-WEB2.pdf. 3 March 2018.

Sweeney, S. 2005. Europe, the State, and Globalisation. Harlow: Pearson Education, Longman.

Taggart, P.A. 2000. Populism. Buckingham: Open University Press.

Toynbee, Arnold J. 1931. The Trend of International Affairs Since the War. International Affairs 10: 803-826.

van Biezen, Ingrid (ed.). 2014. On Parties, Party Systems and Democracy: Selected Writings of Peter Mair. Colchester: ecpr.

Vaughan-Williams, N. 2015. Europe's Border Crisis: Biopolitical Security and Beyond. Oxford: Oxford University Press.

Vittori, D. 2017. Podemos and the Five-Star Movement: Populist, Nationalist or What? Contemporary Italian Politics 9: 142-161.

Vossen, K. 2016. The Power of Populism: Geert Wilders and the Party for Freedom in the Netherlands. London: Taylor \& Francis.

Wallace, W. 1999. The Sharing of Sovereignty: The European Paradox. Political Studies 47: 503-521.

Weyland, Kurt. 2017. Populism: A Political-Strategic Approach. In The Oxford Handbook of Populism, ed. C.R. Kaltwasser, P.A. Taggart, P.O. Espejo, and P. Ostiguy, 47-72. Oxford: Oxford University Press.

Zaslove, Andrej. 2008. Exclusion, Community, and a Populist Political Economy: The Radical Right as an Anti-Globalization Movement. Comparative European Politics 6: 169-189.

Aristotle Kallis is Professor of Modern and Contemporary History at Keele University, UK. His research interests revolve around fascism and the contemporary radical/far-right in transnational terms, with a particular focus on the 'mainstreaming' of extreme views and on the processes that facilitate taboobreaking language and behaviour. He has published on the history of fascism and the radical right; on the rise of far-right extremism in Greece and Germany; on the mainstream-extremism nexus with regard to a number of key themes in the ideology of the far-right, including nationalism and sovereignty; and on antiSemitism and Islamophobia. 